\title{
A South African Perspective on the Existence of an Interest Tax Shield
}

\author{
A J Pienaar \\ Accounting Training Corporation of South Africa, Johannesburg \\ M Shotter \\ School of Accountancy, University of Pretoria
}

\section{ABSTRACT}

This paper investigates whether the use of debt in the capital structure of a company is beneficial to its shareholders. It finds that, in the South African context, gearing has no effect on the value of a company. The use of debt can increase the value of a company in a country where capital profits and interest are taxed equally. This is the result of an interest tax shield, which is directly related to the tax deductibility of interest paid. However, when capital growth and dividends are exempt in the hands of investors, as is the case in South Africa, the interest tax shield does not exist, and there appears to be no benefit in increasing debt.

JEL M41

\section{INTRODUCTION}

In 1958 Modigliani and Miller wrote an article to the affect that capital structure was not relevant to company value. They argued that the value of a company was determined by the capacity of its assets to earn income, and not by the way these assets were financed (Modigliani \& Miller, 1958: 261-97).

Five years later, however, Modigliani and Miller amended their previous article (1963: 433-43). They demonstrated that due to the existence of company taxation, there was indeed an advantage attached to debt financing, which may be referred to as the interest tax shield.

Modigliani and Miller (1963: 436) formulated the value of a company with financial gearing as follows:

$$
V_{g}=V_{u}+t_{c} D_{g} i / i=V_{u}+t_{c} D_{g}
$$

where $V_{g}=$ the market value of a company with financial gearing; 
$V_{u}=$ the value of a similar company without financial gearing;

$t_{c}=$ the company tax rate;

$D_{g}=$ the market value of the debt in the geared company; and

$i=$ the interest rate.

The interest tax shield $\left(t_{c} D_{g}\right)$ can be defined as the tax saving due to (taxdeductible) interest paid on the debt, capitalized at the pre-taxation interest rate.

The Modigliani-Miller propositions have subsequently become an integral part of modern capital structure theory, referred to in most conventional textbooks on financial management. Examples of these are Samuels, Wilkes and Brayshaw (1995: 649-53), Brigham and Gapenski (1996: 364-70), Brealey and Myers (1996: 449-56) and Van Home (1992: 272-3).

Research conducted by Cooley and Heck (1981: 23-33) amongst financial experts from different sectors of the financial and academic world in the USA, indicated that the Modigliani and Miller 1958 article should be regarded as the most significant contribution ever to finance literature: $85 \%$ of 296 respondents included this article as one of the ten most significant contributions to finance literature. This percentage was higher than for any other such contribution to finance.

\section{PROBLEM STATEMENT AND APPROACH TO THE INVESTIGATION}

The questions regarding optimal capital structure and the validity of the Modigliaili-Miller propositions are complicated when approached from a South African perspective. The reason for this is that the majority of the existing literature that deals with the subject originated in the USA and the United Kingdom. There are significant differences between the taxation systems in these countries (especially at the time when Modigliani and Miller produced their work) and South Africa, which impact on the validity of the Modigliani-Miller propositions in the South African taxation context.

The current situation in South Africa is that the Modigliani-Miller theories are taught at tertiary institutions without adapting the material due to differences in the taxation systems. South African finance literature on capital structure theory corresponds exactly to overseas literature. This may be illustrated by two examples: Financial Management (1993: 589) by Correia, Flynn, Uliana and Wormald, and the first South African edition of Fundamentals of Corporate Finance (1996: 432-3) by Ross, Westerfield, Jordan and Firer. Both these textbooks have South African authors or co-authors and are specifically directed 
at the South African market.

This article investigates the benefit obtained from the use of debt in the capital structure of a company, focusing specifically on the existence of an interest tax shield under South African tax legislation. It questions the validity of the interest shield where capital profits (capital growth and dividends) are exempt in the hands of the investor.

The approach of the examination is to firstly compare the distribution of earnings of a company under two different tax systems in order to illustrate that an interest tax shield does not exist where capital profits are exempt in the hands of the investor.

The second part of the paper consists of a review of related but independent empirical research to determine whether the results of these studies support the finding of this paper. Since the four empirical studies were carried out autonomously, they were not designed to specifically test the existence of an interest tax shield. In all four cases though, the studies investigate whether the use of debt in the capital structure is beneficial to the company.

\section{THE VALIDITY OF THE INTEREST TAX SHIELD UNDER SOUTH AFRICAN TAXATION LEGISLATION}

When examining the validity of the interest tax shield, a distinction should be made between a taxation system where capital profits are taxed in the hands of the receiver thereof, for example the USA, and a system where these two items are not included in taxable income, such as South Africa.

The theory of the existence of an interest tax shield was developed in a system where capital profits and dividends were taxed in the same manner as normal company profits and interest received (Brealey \& Myers, 1996). Several adjustments were subsequently made to account for differences between personal and company tax rates and the effect of unrealised capital profits (Miller, 1977; Brealey \& Myers, 1996: 479-84). Nonetheless, the Modigliani and Miller theory regarding the effect of debt in a company's capital structure, in a world with taxes, simply requires that income from debt and equity be taxed at the same rate (Brealey \& Myers, 1996: 480).

In terms of the US taxation system, the rate at which interest and dividends received are taxed in the hands of investors, is the same (Brealey \& Myers, 1996: 475). The US system effectively levies double taxation on company net profit (Miller, 1988: 11), first on corporate and then on personal level. 
However, while interest paid by the company is tax-deductible, dividends paid are not. The US tax system thus results in a saving for the providers of equity capital at the expense of the Receiver of Revenue when debt is included in the capital structure (Brealey \& Myers, 1996: 476; Samuels, Wilkes \& Brayshaw, 1995: 653).

In terms of South African tax legislation, dividends received by investors are currently not taxable. Net profit is taxed only once at corporate level, and consequently there is no saving for the investor when a company uses debt.

The above can best be illustrated by means of a comparison of how $\$$ or R1 million of earnings before interest and tax of a geared and an ungeared company will be distributed amongst debt holders, equity holders and the Receiver of Revenue, under the two tax systems. The first is a system where capital earnings are taxed (as in the USA), whilst in terms of the second dispensation capital earnings are exempt (as in South Africa).

The illustration assumes that debt of R1 million is included in the capital structure of both geared companies at an interest rate of $10 \%$. It also accepts that all after tax income is declared as dividends, and that both the corporate and personal taxation rates are $35 \%$. Secondary Tax on Companies is ignored.

Table 1 A comparison of a distribution of earnings in two tax systems

\begin{tabular}{|l|r|r|r|r|}
\hline & \multicolumn{2}{|c|}{$\begin{array}{c}\text { Capital earnings taxed } \\
\text { (USA) }\end{array}$} & \multicolumn{2}{c|}{$\begin{array}{c}\text { Capital earnings tax } \\
\text { exempt } \\
\text { (South Africa) }\end{array}$} \\
\hline & $\begin{array}{r}\text { Ungeared } \\
\mathbf{S}\end{array}$ & $\begin{array}{c}\text { Geared } \\
\mathbf{S}\end{array}$ & $\begin{array}{c}\text { Ungeared } \\
\text { R }\end{array}$ & $\begin{array}{c}\text { Geared } \\
\text { R }\end{array}$ \\
\hline EbIT & 1000000 & 1000000 & 1000000 & 1000000 \\
Interest @10\% & - & $(100000)$ & - & $(100000)$ \\
\hline EbT & 1000000 & 900000 & 1000000 & 900000 \\
Corporate tax@35\% & $(350000)$ & $(315000)$ & $(350000)$ & $(315000)$ \\
\hline & 650000 & 585000 & 650000 & 585000 \\
\hline Equity holders & & & & \\
\hline Dividends received & 650000 & 585000 & 650000 & 585000 \\
Taxation@35\% & $(227500)$ & $(204750)$ & & - \\
\hline Net & 422500 & 380250 & 650000 & 585000 \\
\hline
\end{tabular}


Table 1 continued

\begin{tabular}{|c|c|c|c|c|}
\hline & \multicolumn{2}{|c|}{$\begin{array}{c}\text { Capital earnings taxed } \\
\text { (USA) }\end{array}$} & \multicolumn{2}{|c|}{$\begin{array}{c}\text { Capital earnings tax } \\
\text { exempt } \\
\text { (South Africa) }\end{array}$} \\
\hline & $\begin{array}{c}\text { Ungeared } \\
\mathbf{s}\end{array}$ & $\begin{array}{c}\text { Geared } \\
\$\end{array}$ & $\begin{array}{c}\text { Ungeared } \\
\mathbf{R}\end{array}$ & $\begin{array}{c}\text { Geared } \\
\text { R }\end{array}$ \\
\hline \multicolumn{5}{|l|}{ Debt holders } \\
\hline $\begin{array}{l}\text { Interest received } \\
\text { Taxation@35\% }\end{array}$ & $\begin{array}{l}- \\
-\end{array}$ & $\begin{array}{r}100000 \\
(35000)\end{array}$ & - & $\begin{array}{r}100000 \\
(35000)\end{array}$ \\
\hline & - & 65000 & - & 65000 \\
\hline \multicolumn{5}{|l|}{ Summary } \\
\hline $\begin{array}{l}\text { Receiver of Revenue } \\
\text { Equity holders } \\
\text { Debt holders } \\
\end{array}$ & $\begin{array}{l}577500 \\
422500\end{array}$ & $\begin{array}{r}554750 \\
380250 \\
65000 \\
\end{array}$ & $\begin{array}{r}350000 \\
650000 \\
- \\
\end{array}$ & $\begin{array}{r}350000 \\
585000 \\
65000 \\
\end{array}$ \\
\hline & 1000000 & 1000000 & 1000000 & 1000000 \\
\hline
\end{tabular}

Source: Pienaar, 1999: 56.

It is clear that the Receiver of Revenue receives a smaller share of the income in the case of a geared company under the US tax system. The difference ( $\$ 22750)$ capitalized at the cost of debt before tax, is the present value of the interest tax shield $(\$ 22750 / 0,1-\$ 227500)$. The theory of the tax shield therefore appears to be correct. There is ultimately a saving for the providers of capital when a company uses gearing, and this saving must revert to the equity holders. However, this only appears to apply in a taxation system where dividends and interest received are taxed equally.

We can see from Table 1 that under South African taxation legislation, the debt and equity holders receive no benefit due to gearing. The Receiver of Revenue does not subsidize any of the interest paid. The fact that interest is tax-deductible merely makes it a cheaper form of corporate finance than it would have been if it had not been tax-decuctible.

From the above comparison it can be deduced that under South African tax legislation, the same principles as described in a Modigliani and Miller world without taxes still apply: gearing has no effect on the value of a company. 


\section{EMPIRICAL RESEARCH RESULTS IN SOUTH AFRICA}

\subsection{Introduction}

The following four studies have directly or indirectly investigated the effect of the use of debt on the value of South African companies. Davidson and Rapp (1995) inter alia examined the effect of gearing on return on equity and Fasol and Firer (1995) studied the reasons why very few companies were prepared to take up additional debt in an attempt to lower their cost of capital. Whilst Uliana (1993) considered the effect of the debt-equity ratio on the growth of share prices, Shotter, Brümmer, Dennis and Boshoff (1998) investigated the correlation between shareholders' wealth and capital structure. These studies are reviewed to assess whether the results of independent empirical investigations are consistent with the deduction made in this study.

\subsection{Davidson and Rapp}

Davidson and Rapp (1995: 90) made an inquiry into the use of debt amongst South African companies. The research population consisted of the Finance Week 200 group of listed companies and the period investigated was from 1989 to 1991. They identified two possible reasons for the use of debt: (1) as a method of obtaining finance, and (2) as a technique for regulating the shareholdermanagement relationship. The latter is accomplished when management is forced to pay interest on a regular basis. This prevents them from investing large amounts of cash at their own discretion, which may be detrimental to shareholders (Davidson \& Rapp, 1995: 91).

Davidson and Rapp (1995: 94) found that financial risk did not affect return on equity. They argued that one of the reasons for this was that there was hardly any $\operatorname{tax}$ advantage to the use of debt. They used the formula developed by Miller (1977: 267), $D \times\left\{1-\left[\left(1-t_{c}\right)\left(1-t_{p s}\right) /\left(1-t_{p d}\right)\right]\right\}$, where $D$ represents the market value of debt, $t_{c}$ the corporate taxation rate, $t_{p s}$ the personal taxation rate on equity income, and $t_{p d}$ the personal taxation rate on interest received, and showed that the advantage of using debt was minimal.

In $1991 t_{c}$ was $50 \%, t_{p s}$ was nil, and the marginal taxation rate on interest received $\left(t_{p d}\right)$ was $45 \%$. If these values are substituted in the formula, it appears that the tax advantage of debt was minimal $-D \times 0,0909$. In the case where a company's effective taxation rate is lower than the personal taxation rate, the factor with which the debt component is multiplied, becomes negative, with the result that the use of debt is to the company's detriment. 
The research conducted by Davidson and Rapp confirms that, due to the absence of an interest tax shield, there appears little advantage in the use of debt.

\section{Fasol and Firer}

Fasol and Firer's research (1995: 75) included a sample of 222 listed South African companies. Although $62 \%$ of the respondents indicated that they had spare capacity for additional gearing, very few were prepared to take up additional debt in an attempt to lower the company's cost of capital.

The main reasons for this were (1) to maintain a strong cash flow, (2) a lack of good investment opportunities, (3) the negative impact on financial ratios, and (4) the perception that additional debt would not decrease, but rather increase, the company's cost of capital. The last aspect supports the view that the use of debt in a capital structure is not beneficial to shareholders in South Africa, which might be ascribed to the fact that an interest tax shield does not exist.

\subsection{Uliana}

Uliana (1993: 61-8) examined 135 companies listed on the Johannesburg Stock Exchange, to determine the effect of the return on assets and the debt-equity ratio on the growth of each company's share price.

The research covered the period 1987 to 1992 , and growth was determined by comparing the share price at the beginning of the period to the value at the end of the period. The average prime bank rate during the period of the research was $17,96 \%$, which was lower than the return on assets (Uliana, 1993: 66).

Uliana refers to Zakon's formula (in Uliana, 1993: 61) to determine sustainable growth:

$S G R=D / E\left[p_{a}-i\left(i-t_{c}\right)\right] R_{p}+p_{o} R_{p}$

where:

$S G R=$ sustainable growth

$D=$ debt

$E=$ equity

$p_{a}=$ return on assets

$i=$ interest rate

$t_{c}=$ company taxation rate

$R_{p} \quad=\quad$ rate of retention of profits after tax. 
According to this formula it is expected that companies with a higher return on assets $\left(p_{c}\right)$ would show higher sustainable growth than companies with a lower return on assets. Similarly, it is anticipated that companies with a high debt-equity ratio would experience higher sustainable growth than companies with a low debt-equity ratio, especially where the return on assets is higher than the interest rate.

The investigation revealed that companies with a higher retum on assets $\left(p_{a}\right)$ experienced a significantly higher sustainable growth. This is in accordance with Zakon's formula for sustainable growth. However, with regard to the debt-equity ratio, companies with a lower debt-equity ratio experienced more growth than companies with a higher debt-equity ratio. This is contradictory to Zakon's formula (Uliana, 1993: 65).

Uliana (1993: 66) divided the total sample into two groups, namely the lower debt-equity ratio companies in one group, and the higher debt-equity ratio companies in the other. The results of the research pertaining to the debt-equity analysis can be summarized as follows:

Table 2 The results of the debt-equity analysis

\begin{tabular}{|l|c|c|}
\hline & Lower D/E & Higher D/E \\
\hline Average growth & 3,25 & 1,77 \\
Number of observations & 68 & 67 \\
Average return on assets & $19,41 \%$ & $18,56 \%$ \\
Average retention ratio & $61,64 \%$ & $65,96 \%$ \\
\hline
\end{tabular}

Table 2 shows that neither the return on assets nor the average retention ratio of the two groups differed significantly. Yet the group with the lower debt-equity ratio experienced substantially more growth $(3,25$ times) than the group with the higher debt-equity ratio ( 1,77 times).

Uliana's (1993: 66) interpretation of this phenomenon is that sustainable value can only be achieved through fundamental operations such as operational efficiency, and not necessarily through the use of debt.

These findings support the absence of an interest tax shield within the South African tax enviromment.

\subsection{Shotter, Brümmer, Dennis and Boshoff}

Shotter, Brümmer, Dennis and Boshoff (1998: 301-17) conducted empirical 
research to investigate the correlation between shareholders' wealth and EVA (Economic Value Added) as well as other traditional indicators of shareholders' wealth. EVA is the residual income after subtracting the cost of all capital, including equity, that has been employed to generate the operating profit.

They identified MVA (Market Value Added) as the measure of shareholders' wealth. MVA is defined as market capitalization plus the market value of preference shares and total debt less the carrying value of total debt and equity. Market capitalization is based on the equivalent number of fully paid-up ordinary shares at the end of the company financial year times the average price of shares traded during the month of the company financial year-end. Total debt is described as total long-term loans, short-term loans and bank overdrafts (Shotter et al., 1998: 303).

The research examined the relation between MVA and the following traditional indicators of shareholders' wealth: cash flow per share, earnings per share, headline eamings per share, dividend per share, return on equity, capital structure, and EVA.

The population included all companies listed on the Johannesburg Stock Exchange during the period 1987 to 1996, with the exception of financial institutions, mining companies, shell, pyramids and property holding companies. A total of 135 companies were examined.

A Pearson correlation coefficient analysis was performed with market value added as the dependent variable and the other indicators as independent variables. The analysis was carried out at a $1 \%$ level of significance.

\section{Table 3 The correlation between MVA and other indicators}

\begin{tabular}{|l|c|c|}
\hline & Total period & Significance \\
\hline EVA & 0,155 & 0,0001 \\
Cash flow per share & 0,048 & 0,0822 \\
Earmings per share & 0,102 & 0,0002 \\
Headline earnings per share & 0,068 & 0,0146 \\
Dividend per share & 0,079 & 0,0044 \\
Return on equity & 0,061 & 0,0289 \\
Capital structure & 0,001 & 0,9800 \\
\hline
\end{tabular}

On the basis of the above data it appears that the strongest correlation over the period as a whole was between MVA and EVA, followed by earnings per share and dividend per share. 
The weakest correlation was between MVA and capital structure, namely 0,001 . During four of the ten years the correlation was negative. This is inconsistent with Modigliani and Miller's (1963) amended view, that an increase in debt increases shareholders' value.

These results again support the deduction made in this paper, namely that there is little if any advantage to debt within the South African taxation context.

\section{CONCLUSION}

There appears to be no benefit to shareholders if the proportion of debt in the capital structure is increased, under South African circumstances. The proposed increase in shareholders' value as suggested by Modigliani and Miller (1963) depends on the existence of an interest tax shield. However, such a shield only arises where capital income and interest are taxed equally, as is the case in the United States of America. In South Africa, dividends and capital growth are exempt in the hands of investors, meaning that an interest tax shield does not exist.

These findings have implications for Financial Management theory and practice in South Africa. Whenever modern capital structure theory is taught or explained in textbooks, the limiting assumptions that accompany these theories should be stressed. If the theory in respect of the existence of the interest tax shield could be modeled on South African circumstances, it would be evident that gearing holds no benefit to shareholders. 


\section{APPENDIX A}

\section{List of symbols}

$D_{8} \quad=\quad$ the market value of the debt in the geared company; and

$D=$ debt

$E=$ equity

EbIT $=$ earnings before interest and tax

$\mathrm{EbT}=$ earnings before tax

EVA $=$ Economic Value Added

$i=$ interest rate

MVA $=$ Market Valued Added

$p_{a}=$ retum on assets

$R_{p} \quad=\quad$ rate of retention of profits after tax

SGR $=$ sustainable growth

$t_{c} \quad=$ the company taxation rate;

$t_{p d}=$ the personal taxation rate on interest received

$t_{p s}=$ the personal taxation rate on equity income

$V_{g}=$ the market value of a company with financial gearing;

$V_{u}=$ the value of a similar company without financial gearing; 


\section{REFERENCES}

1 BREALEY, R.A. and MYERS, S.C. (1996) Principles of Corporate Finance $\left(5^{\text {th }}\right.$ ed.) McGraw-Hill, New York.

2 BRIGHAM, E.F. and GAPENSKI, L.C. (1996) Intermediate Financial Management $\left(5^{\text {th }}\right.$ ed.) The Dryden Press, Fort Worth.

3 COOLEY, P.L. and HECK, J.L. (1981) "Significant Contributions to Finance Literature", Financial Management, Tenth Anniversary Issue, 1981: 23-33.

4 CORREIA, C., FLYNN, D., ULIANA, E. and WORMALD, M. (1993) Financial Management $\left(3^{\text {rd }}\right.$ ed) Juta \& Co, Ltd, Cape Town.

5 DAVIDSON, S. and RAPP, L. (1995) "The Corporate Uses of Debt", South African Journal for Business Management, 26(3),

6 FASOL, R. and FIRER, C. (1995) "Do South African Managers Focus on the Creation of Shareholder Value?" South African Joumal for Business Management, 26(2).

7 MARSH, P. (1982) "The Choice Between Equity and Debt: An Empirical Study", Joumal of Finance, March 1982.

8 MILLER, M.H. (1977) "Debt and Taxes", Journal of Finance, 32: 261-76.

9 MILLER, M.H. (1988) "The Modigliani-Miller Propositions after Thirty Years", Journal of Applied Corporate Finance, 1988.

10 MODIGLIANI, F, and MILLER, M.H. (1958) "The Cost of Capital, Corporation Finance and the Theory of Investment", American Economic Review, 48: 261-97 (June 1958).

11 MODIGLIANI, F, and MILLER, M.H. (1963) "Corporate Income Taxes and the Cost of Capital: a Correction, American Economic Review", 53: 433-43 (June 1963).

12 PIENAAR, A.J. (1999) 'n Suid-Afrikaanse Perspektief op die Teorie van Optimale Kapitaalstruktuur, Unpublished masters thesis, University of Pretoria.

13 SAMUELS, J.M., WILKES, F.M. and BRAYSHAW, R.E. (1995) Management of Company Finance ( $6^{\text {th }}$ ed.) Chapman \& Hall, London.

14 SHOTTER, M., BRÜMMER, L., DENNIS C. and BOSHOFF A. (1998) "Creation of Shareholder Value: A Comparison of Economic Value Added (EVA) with Traditional Performance Measures", Meditari, 6: 301-17.

15 ULIANA, E. (1993) "The Attainment of Growth through Debt", Meditari, 1: 61-8.

16 VAN HORNE, J.C. (1992) Financial Management and Policy (9th ed.) Prentice-Hall, Inc. Englewood Cliffs, New Jersey. 